- e ISSN-0976-6855 | Visit us : www.researchjournal.co.in

\title{
Evaluation of new insecticides and bio pesticides against defoliators on Palak
}

\author{
Y.K. KOTIKAL* AND K.N. MANJULA
}

Department of Entomology, University of Horticultural Sciences, BAGALKOT (KARNATAKA) INDIA

\section{ARITCLE INFO}

Received : 14.06 .2016

Revised : 01.08 .2016

Accepted : 15.08 .2016

\section{KEY WORDS :}

Agrotis segetum, Emamectin benzoate, Fipronil, Indoxacarb, Palak, Spoladea recurvalis

*Corresponding author:

Email : dsw@uhsbagalkot.edu.in

\begin{abstract}
The investigation was undertaken at the College of Horticulture, UHS, Bagalkot, during 2013-2014 to study the bio efficacy of different insecticides against Agrotis segetum (Denis and Schiffermuller) and Spoladea (=Hymenia) recurvalis (Fabricius) on Palak. The results indicated that the newer molecules viz., emamectin benzoate 5 per cent SG @ 0.25g/lit indoxacarb 15.8 per cent EC @ 0.25 ml/lit and fipronil 5 per cent SC @ 1ml/ lit were found very effective in minimizing the larval population and were superior in reducing the foliage damage and also fetched higher yields of 15.00, 15.11 and 15.33 $\mathrm{t} / \mathrm{ha}$, respectively throughout period of experiment. The highest ICBR (50.21) was obtained from the treatment indoxacarb 15.8 per cent EC @ $0.25 \mathrm{ml} / \mathrm{lit}$.
\end{abstract}

How to view point the article : Kotikal, Y.K. and Manjula, K.N. (2016). Evaluation of new insecticides and bio pesticides against defoliators on Palak. Internat. J. Plant Protec., 9(2) : 365371, DOI : 10.15740/HAS/IJPP/9.2/365-371. 